\title{
Upaya Meningkatkan Motivasi Dan Hasil Belajar Pendidikan Agama Islam Dan Budi Pekerti Peserta Didik Kelas VI Semester Satu Tahun Pelajaran 2019/2020 Di SD Negeri 12 Ampenan Dengan Mengoptimalkan Penerapan Model Group Resume (Resume Kelompok)
}

\author{
Masni \\ Guru Pendidikan Agama Islam Dan Budi Pekerti SD Negeri 12 Ampenan
}

\begin{abstract}
Abstrak. Penelitian ini bertujuan untuk mengetahui efektifitas penerapan Group Resume (Resume Kelompok) dalam upaya meningkatkan motivasi belajar Pendidikan Agama Islam Dan Budi Pekerti Peserta Didik Kelas VI SD Negeri 12 Ampenan. Manfaat penelitian ini adalah sebagai bahan kajian dan bahan temuan dalam pelaksanaan proses pembelajaran di kelas senyatanya. Bagi guru untuk meningkatkan kompetensi dalam proses pembelajaran dan bagi Peserta Didik untuk meningktakan motivasi belajar yang berdampak meningkatnya hasil belajar Peserta Didik. Penelitian ini dilaksanakan dua siklus, masing-masing siklus kegiatannya adalah; perencanaan, pelaksanaan, observasi dan refleksi. Hasil akhir tindakan pada siklus II pertemuan II menunjukkan bahwa hasil observasi guru memperoleh skor rata-rata $(4,57)$ dan hasil observasi Peserta Didik mencapai skor rata-rata $(4,51)$. Sedangkan dampak dari peningkatan motivasi belajar adalah meningkatnya perolehan hasil belajar Peserta Didik mencapai nilai rata-rata $(80,09)$, artinya indikator keberhasilan $(\geq 4,0)$ telah terlampaui. Karena indicator keberhasilan telah terbukti penelitian dinyatakan berhasil dan dihentikan pada siklus II.
\end{abstract}

\section{Kata Kunci : Motivasi dan Hasil Belajar-Group Resume (Resume Kelompok)}

\section{PENDAHULUAN}

\section{Latar Belakang}

Motivasi belajar bisaanya cepat muncul ketika peserta didik sedang melakukan diskusi dalam kelompok kecil.Setelah hasil diskusi kelompok telah mencapai kata mufakat, maka kegiatan berikutnya yang memerlukan motivasi yaitu ketika kelompok menyusun laporan/resume hasil dari diskusi kelompok.Bisaanya sebuah resume menggambarkan hasil yang telah dicapai oleh individu-individu. Resume ini akan menjadi lebih menarik untuk dilakukan dalam group (kelompok kecil) dengan tujuan membantu peserta didik menjadi lebih akrab atau melakukan team building (kerjasama kelompok) yang anggotanya sudah saling mengenal sebelumnya. Kegiatan ini akan lebih efektif jika resume itu berkaitan dengan materi yang sedang dibahas dalam proses pembelajaran di kelas/di musola sekolah. Proses pembelajaran yang mengedepankan peran aktif dari seluruh peserta didik dalam kegiatan diskusi kelompok sangat efektif dalam upaya meningkatkan motivasi dan hasil belajar Pendidikan Agama Islam dan Budi Pekerti.

Proses pembelajaran Pembelajaran Pendidikan Agama Islam Dan Budi Pekertidi kelas VI SD Negeri 12 Ampenan pada semester satu tahun pelajaran 2019/2020 sudah menerapkan model pembelajaran peserta didik aktif. Bentuk riil penerapan model pembelajaran ini adalah model diskusi kelompok kecil. Selama proses diskusi berjalan lancar, hampir semua anggota pada masingmasing kelompok ikut ambil bagian dalam memecahkan permassalahan yang menjadi tugaas dan tanggung jawab kelompok. Akan tetapi ketika kelompok itu ingin membuat resume hasil kesepakatan kelompok mengalami kendala dan mengalami hambatan. Kendala dan hambatan itu disebabkan kurangnya daya piker dan intelektualitas peserta didik terutama dalam menyusun kata-kata ataupun kalimat antara peserta didik satu dengan yang lainnya sangat sulit dPendidikan Agama Islam Dan Budi Pekertidukan.

Rendahnya motivasi dan hasil belajar peserta didik kelas VI semester satu tahun 
Jurnal Ilmiah Mandala Education

http://ejournal.mandalanursa.org/index.php/JIME/index

terakreditasi Peringkat 4 (No. SK: 36/E/KPT/2019)

pelajaran 2019/2020 di SD Negeri 12 Ampenan khususnya pada pembelajaran bidang studi Pendidikan Agama Islam Dan Budi Pekerti disebabkan karena: 1) kurang optimalnya pelaksanaan model "Group Resume (Resume Kelompok), 2) kemampuan peserta didik dalam membuat resume kelompok masih sangat kurang, terutama dalam menyusun kata-kata dan kalimat yang pas dan bisa dPendidikan Agama Islam Dan Budi Pekertihami oleh semua orang yang berkepentingan dengan peningkatan motivassi dan hassil belajar peserta didik kelas VI semester satu tahun pelajaran 2019/2020 khususnya pada bidang studi Pendidikan Agama Islam Dan Budi Pekerti, dan 3) kurang kompaknya antar individu dalam kelompok dalam penyusunan kata-kata ataupun kalimat pada hasil karya kelompok yang berupa Resuma kelompok (Group Resume).

Banyak solusi yang bisa dilakukan oleh peneliti/guru bidang studi Pendidikan Agama Islam dan Budi Pekerti, alternative yang dilakukan yaitu dengan mengoptimalkan penerapan model "Group Resume (Resume Kelompok)". Adapun alasannya yaitu karena model "Group Resume (Resume Kelompok)" mempunyai beberapa keunggulan bila dibandingkan dengan model pembelajaran yang lain. Keunggalan-keunggulan itu antara lain: 1) resume menggambarkan hasil yang telah dicapai oleh individu-individu dalam kelompok kemudian dimodifikasi sehingga hasilnya merupakan keputusan final dari seluruh pendapat individu dalam kelompok, 2)resume sangat menarik karena dilakukan dalam group dengan tujuan membantu peserta didik menjadi lebih akrab selama proses kerjasama dalam kelompok yang anggotanya saling mengenal dan saling asah dan asuh dalam kebersamaan di kelompoknya masing-masing, dan 3)kegiatan Group Resume sangat efektif karena yang dipermasalahkan berhubungan dengan materi pelajaran yang sedang dibicarakan oleh guru dalam waktu yang beruntun.

Rendahnya motivasi dan hasil belajar Pendidikan Agama Islam Dan Budi Pekerti dapat diminimalkan dan bisa ditingkatkan
Vol. 6. No. 1. April 2020

p-ISSN: 2442-9511 e-ISSN: 2656-5862

dengan mengoptimalkan penerapan model "Group Resume". Untuk meyakinkan dugaan itu maka perlu diadakan Penelitian Tindakan Kelas (PTK) dengan judul "Upaya Meningkatkan Motivasi Dan Hasil Belajar Pendidikan Agama Islam Dan Budi Pekerti Peserta Didik Kelas VI Semester Satu Tahun Pelajaran 2019/2020 Di SD Negeri 12 Ampenan Dengan Mengoptimalkan Penerapan Model Group Resume (Resume Kelompok)".

\section{Rumusan Masalah}

"bagaimana penerapan model Group Resume (Resume Kelompok) pada bidang studi Pendidikan Agama Islam Dan Budi Pekerti peserta didik kelas VI semester satu tahun pelajaran 2019/2020 upaya meningkatkan motivasi dan hasil belajar di SD Negeri 12 Ampenan?".

\section{Tujuan penelitian}

- Untuk mengetahui sejauh mana efektivitas penerapan model pembelajaran Group Resume (Resume Kelompok) dalam upaya meningkatkan motivasi dan hasil belajar Pendidikan Agama Islam Dan Budi Pekerti peserta didik Kelas VISD Negeri 12 Ampenan.

- Untuk mengetahui peningkatan motivasi dan hasil belajar peserta didik Kelas VISD Negeri 12 Ampenantahun pelajaran 2019/2020 sebagai dampak dari penerapan model pembelajaran Group Resume (Resume Kelompok).

\section{Manfaat Penelitian}

- Bermanfaat bagi guru selaku peneliti dalam rangka melaksanakan proses pembelajaran yang kontekstual melalu penerapan model pembelajaran Group Resume (Resume Kelompok) di kelas senyatanya serta dalam upaya perwujudan pembelajaran yang aktif, inovatif, kreatif, efektif, dan menyenangkan (PAIKEM) sehingga motivasi peserta didik dapat ditingkatkan.

- Bagi peserta didik sangat bermanfaat dalam upaya peningkatan motivasi dan hasil belajar yang berdampak meningkatnya prestasi belajar peserta didik. 
Jurnal Ilmiah Mandala Education

http://ejournal.mandalanursa.org/index.php/JIME/index

terakreditasi Peringkat 4 (No. SK: 36/E/KPT/2019)

\section{KAJIAN PUSTAKA}

\section{Motivasi}

Motivasi dapat diartikan serangkaian usaha menyediakan kondisi-kondisi tertentu, sehingga seorang itu mau dan ingin melakukan sesuatu dan bila ia tidak suka, maka akan berusaha meniadakan dan meyalahkan perasaan tidak suka itu (Sardiman, 2007). Pendapat lain mengatakan bahwa motivasi dan hasil belajar adalah merupakan faktor fisik yang bersifat non intelektual (Hil,2002). Peserta didik yang memiliki motivasi yang kuat, akan mempunyai banyak energy untuk melakukan kegiatan (Sardiman, 2007). Jika guru memiliki suatu kejelasan ide mengenai arah program pembelajaran peserta didik dapat diberi kebebasan untuk menyesuaikan bahan dan program tersebut pada suatu arah dan konteks dari pilihannya sendiri (Nurhaadi, 2003). Jika peserta didik berpartisPendidikan Agama Islam Dan Budi Pekertisi dalam pembuatan perencanaan pengalaman belajarnya sendiri, motivasi peserta didikakan meningkat dan terjaga dengan baik.

Dalam penelitian ini, motivasi dan hasil belajar yang akan diukur adalah pola belajar peserta didik dalam proses pembelajaran Pendidikan Agama Islam Dan Budi Pekerti di kelas yaitu sikap antusias terhadap materi yang diajarkan. Prilaku untuk anak bekerjasama dalam kelompok kecil, keaktifan dalam melaksanakan kerjasama dalam kelompok, kemampuan tiap-tiap peserta didik untuk menjawab pertanyaan dari teman sejawat maupun yang berasal dari guru mata pelajaran, dan yang terakhir adalah kemampuan peserta didik untuk memanage waktu yang diberikan oleh guru untuk masing-masing kelompok.

\section{Hasil belajar}

Mukhtar (2003:54) mengatakan bahwa pengertian hasil belajar tidak dapat dipisahkan dan apa yang terjadi dalam aktifitas pembelajaran baik di kelas maupun diluar kelas. Apa yang dialami oleh peserta didik dalam proses pengembangan kemampuannya merupakan apa yang diperoleh dalam belajar dan pengalaman tersebut pada akhirnya dipengaruhi oleh beberapa faktor diantaranya keadaan kognitif, afektif dan psikomotornya pada waktu belajar. Kualitas pengajaran yang diterimanya dan cara pengelolaan proses interaksi yang dilakukan oleh guru.

Masalah evaluasi hasil belajar meliputi alat ukur yang digunakan, cara menggunakan, cara penilaian dan evaluasinya (Harus Rasid dan Mansur, 2008:9). Evaluasi hasil belajar yang berhubungan dengan tugas guru rutin dilakukan evaluasi hasil, yang juga dijadikan umpan balik, evaluasi hasil bertujuan menilai apakah hasil belajar dicapai sesuai dengan tujuan (Lukmanul Hakim, 2008:165).

Pakar pendidikan lain mendefinisikan bahwa yang dimaksud hasil belajar adalah perubahan perilaku secara keseluruhan bukan salah satu aspek potensi kemanusiaan saja (Supriyono, 2009:19). Berbeda dengan pendapatnya Bloom (Dalam Sumiati danAska, 2008).Hasil belajar mencakup kemampuan kognitif, afektif, dan psikomotorik. Jadi pendapat ini mengisyaratkan bahwa haasil belajar peserta didik harus diukur dengan tes tertulis, tes sikap, dan kemampuan skil secara nyata selama proses pembelajaran di kelas senyatanya.

Dalam penelitian ini yang dimaksud dengan hasil belajar adalah tes ulangan harian yang dilaksanakan secara tertulis pada akhir pembelajaran.

\section{Group Resume (Resume Kelompok)}

Biasanya sebuah resume menggambarkan hasil yang telah dicapai oleh individu. Resume ini akangroup dengan tujuan membantu siswa/mahasiswa menjadi lebih akrab atau melakukan team building (kerjasama kelompok) yang anggotanya sudah saling mengenal sebelumnya. Kegiatan ini akan lebih efektif jika resume itu berkaitan dengan materi yang sedang anda ajarkan. menjadi menarik untuk dilakukan dalam

\section{Langkah-langkah:}

1. Bagi siswa/ menjadi beberapa kelompok kecil terdiri dari 3 - 6 anggotanya, 
2. Terangkan kepada siswa bahwa kelas mereka itu dipenuhi oleh individu-individu yang penuh bakat dan pengalaman,

3. Sarankan bahwa salah satu cara untuk mengidentifikasi dan menunjukan kelebihan yang dimiliki kelas dengan membuat resume kelompok,

4. Bagikan kepada setiap kelompok kertas plano (kertas buram koran) dan spidol untuk menuliskan resume mereka. Resume harus dapat mencakup informasi yang dapat menjual "kelompok" secara keseluruhan.

\section{Hipotesis Tindakan.}

Penerapan pendekatan Group Resume (Resume Kelompok) dapat meningkatkan motivasi dan hasil belajarPendidikan Agama Islam Dan Budi Pekertipeserta didikKelas VISD Negeri 12 AmpenanSemester satu tahun pelajaran 2019/2020.

\section{PROSEDUR PENELITIAN}

\section{Setting Penelitian}

Penelitian tindakan kelas (PTK) ini akan dilaksanakan di Kelas VISD Negeri 12 AmpenanSemester satuTahun pelajaran 2019/2020, dengan jumlah peserta didik sebanyak 30 orang peserta didik.

\section{Faktor yang Diteliti}

- Faktor Guru: yaitu dengan mengganti cara guru membuat Rencana Pelaksanaan Pembelajaran (RPP) dan pelaksanaannya dalam pembelajaran di kelas senyatanya dengan menerapkan pendekatan Group Resume (Resume Kelompok) dalam upaya meningkatkan motivasi dan hasil belajar Pendidikan Agama Islam Dan Budi Pekerti peserta didik Kelas VISD Negeri 12 Ampenan.

- Faktor Peserta didik: yaitu peningkatan motivasi dan hasil belajar peserta didik yang terlihat pada perilaku peserta didik selama diskusi kelompok, dan pada saat mengerjakan tes tertulis.

\section{Rencana Tindakan}

Tindakan nyata yang dilakukan oleh guru selaku peneliti adalah dengan menggunakan siklus.Gambaran siklus dalam penelitian ini adalah sebagai berikut:

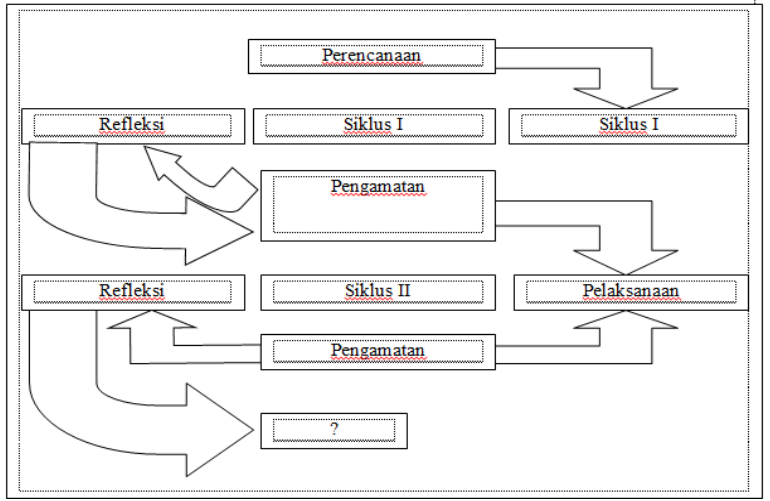

Setiap siklus selama penelitian ini berisi 4 (empat) tahapan yaitu: 1) Perencanaan (Planning), 2) Pelaksanaan (Action), 3) Observasi (Observation), dan 4) Refleksi (Reflection).

\section{Siklus Tindakan}

\section{SIKLUS I}

\section{Tahap Perencanaan (Planning)}

1. Pada tahapan ini guru selaku peneliti melakukan kegiatan-kegiatan sebagai berikut:

2. Menyusun Rencana Pelaksanaan Pembelajaran (RPP) dengan skenario sesuai dengan aturan main model pembelajaran Group Resume (Resume Kelompok).

3. Menyiapkan sumber, bahan, dan semua alat yang digunakan dalam penelitian.

4. Menyusun/membuat lembar observasi guru dan lembar observasi peserta didik.

5. Menyusun alat evaluasi.

\section{Tahap Pelaksanaan (Action)}

\section{Pertemuan I}

1. Guru membagi peserta didik menjadi 5 (lima) kelompok yang anggotanya masingmasing berjumlah 6 orang peserta didik

2. Guru menjelaskan kepada peserta didik bahwa kelas mereka itu dipenuhi oleh individu-individu yang penuh bakat dan pengalaman,

3. Masing-masing kelompok dibagikan kertas plano (kertas buram koran) dan spidol untuk menuliskan resume mereka. Resume harus dapat mencakup informasi yang 
dapat menjual "kelompok" secara keseluruhan.

4. Diskusikan materi yang akan dibuat resume dari hasil diskusi kelompok masing-masing

\section{Pertemuan II}

5. Guru memberikan kesempatan kepada masing-masing kelompok untuk mempresentasikan resume mereka dan catat keseluruhan potensi yang dimiliki oleh keseluruhan kelompok.

6. Tes tertulis

\section{Tahap Observasi (Observation)}

1. Observasi guru :

Dilakukan oleh pengawas mata pelajaran Pendidikan Agama Islam Dan Budi Pekerti observer sekaligus sebagai pembimbing guru dalam melaksanakan Penelitian Tindakan Kelas (PTK).

2. Observasi Peserta didik :

Dilaksanakan oleh guru mata pelajaran sekaligus sebagai peneliti dalam Penelitian Tindakan Kelas (PTK) pada kegiatan diskusi kelompok.

\section{Tahap Refleksi (Reflection)}

1. Renungan hasil perolehan data

2. Pengolahan dan analisa data hasil penelitian

3. Mencocokkan hasil analisa data dengan indikator keberhasilan

4. Rencana perbaikan dan tindak lanjut

SIKLUS II

Pada siklus ini semua kegiatan dan tahapan selama penelitian adalah sama, sifatnya mengulang dan memperbaiki terhadap tindakan yang masih memerlukan penyempurnaan dan pembenaran sebagaimana mestinya.

\section{Data dan Cara Pengambilannya.}

\section{Sumber Data}

Yang menjadi sumber data dalam penelitian tindakan kelas (PTK) ini adalah semua peserta didikKelas VISemester satu tahun pelajaran 2019/2020 di SD Negeri 12 Ampenan dan semua tim peneliti.

\section{Jenis Data}

- Jenis data yang berasal dari guru selaku peneliti

1). Data tentang Rencana Pelaksanaan Pembelajaran (RPP)
2). Data Pelaksanaan Pembelajaran

- Jenis data yang berasal dari peserta didik :

1). Data kemajuan motivasi dari peserta didik

2). Data hasil belajar peserta didik

\section{Cara Pengambilan data}

- Data kegiatan pembelajaran diambil dari RPP yang dibuat oleh guru dan lembar observasi pelaksanaan model pembelajaran Group Resume (Resume Kelompok)

- Data kemajuan motivasi dan hasil belajar; diambil dari lembar observasi selama diskusi kelompok.

- Data kemajuan hasil belajar; diambil dari nilai pada saat tes tertulis yang dilaksanakan pada akhir proses pembelajaran.

Indikator Keberhasilan dan Teknik analisa data

\section{Teknik analisa data}

Untuk menganalisis data akan dilakukan melalui analisis deskriptif kuantitatif melalui pendataan, analisis dan pembahasan terhadap data yang diperoleh dengan mencocokkan tingkat keoptimalan terhadap capaian indikator keberhasilan yang ada.

\section{Indikator Keberhasilan}

- guru telah dinyatakan berhasil melaksanakan proses pembelajaran dengan pendekatan Group Resume (Resume Kelompok), bila telah mencapai skor rata-rata $\geq 4,00$

- Motivasi dan hasil belajar Pendidikan Agama Islam Dan Budi Pekertipeserta didikKelas VI dinyatakan telah meningkat jika $\geq 85 \%$ dari jumlah peserta didik telah memperoleh skor perolehan skor rata-rata $\geq$ 4,0 , hasil belajar dinyatakan meningkat jika $\geq 85 \%$ dari jumlah peserta didik memperoleh nilai rata-rata $\geq 75,00$ (Sesuai KKM)

\section{LAPORAN HASIL DAN PEMBAHASAN DESKRIPSI SIKLUS I}

Tahap Perencanaan

Pada tahapan ini yang telah dilakukan oleh guru selaku peneliti adalah; 1) menyusun RPP dengan skenario pembelajaran Group 
Resume (Resume Kelompok), 2) telah berhasil menyiapkan alat, sumber, bahan yang diperlukan dalam penelitian, 3) berhasil menyusun instrument observasi guru dan instrument observasi peserta didik, dan 4) menyusun alat evaluasi.

\section{Tahap Pelaksanaan}

Pada tahap pelaksanaan proses pembelajaran dengan pendekatan Group Resume (Resume Kelompok) ini yang dilakukan oleh guru adalah

\section{Pertemuan I}

1. Guru membagi peserta didik menjadi 5 (lima) kelompok yang anggotanya masingmasing berjumlah 6 orang peserta didik

2. Guru menjelaskan kepada peserta didik bahwa kelas mereka itu dipenuhi oleh individu-individu yang penuh bakat dan pengalaman,

3. Masing-masing kelompok dibagikan kertas plano (kertas buram koran) dan spidol untuk menuliskan resume mereka. Resume harus dapat mencakup informasi yang dapat menjual "kelompok" secara keseluruhan.

4. Diskusikan materi yang akan dibuat resume dari hasil diskusi kelompok masing-masing

\section{Pertemuan II}

5. Guru memberikan kesempatan kepada masing-masing kelompok untuk mempresentasikan resume mereka dan catat keseluruhan potensi yang dimiliki oleh keseluruhan kelompok.

6. Tes tertulis

\section{Tahap Observasi}

Observasi guru memperoleh skor rata-rata pertemuan I $(3,21)$ dan pertemuan II $(3,64)$. Observasi peserta didik memperoleh skor ratarata pertemuan I $(3,30)$ dan pertemuan II $(3,57)$. Dampak dari hasil peningkatan motivasi dan hasil belajar yang dilihat dari tugas dan tes tertulis memperoleh nilai rata-rata sebesar (70,07) dan (71,97).

\section{Tahap Refleksi}

1. Renungan data hasil perolehan data pada siklus I
2. Pengolahan data hasil observasi guru, peserta didik dan tes tertulis.

3. Mencocokkan hasil yang ada dengan Indikator keberhasilan.

4. Merencanakan perbaikan terhadap jenis tindakan yang menyebabkan belum tuntas Indikator keberhasilan. Oleh karena Indikator keberhasilan belum terbukti maka penelitian dilanjutkan ke siklus II.

\section{DESKRIPSI SIKLUS II}

\section{Tahap Perencanaan}

Pada tahapan ini jenis kegiatan yang dilakukan masih mengacu pada kegiatan siklus I, bedanya hanya terjadi perbaikan seperlunya yaitu: 1) penyusunan RPP dengan mengacu pada pendekatan Group Resume (Resume Kelompok) dan penyempurnaan pada bagian skenario pembelajaran, 2) menyiapkan alat, sumber, bahan yang diperlukan dalam proses tindakan dikelas senyatanyan, 3) menyiapkan lembar observasi guru dan lembar observasi peserta didik sebagaimana pada siklus I, 4) menyiapkan alat evaluasi sebagaimana yang telah dibuat pada siklus I.

\section{Tahap Pelaksanaan}

Secara umum tahapan pelaksanaan proses pembelajaran pada siklus II ini masih mengacu pada pelaksanaan proses pembelajaran sebelumnya. Pemecahan yang dilakukan pada proses pembelajaran ini adalah: 1) pelaksanaan proses diskusi kelompok kecil lebih dioptimalkan, 2) pelaksanaan pembimbingan kelompok sekaligus observasi peserta didik lebih di efektifkan. Utamanya pengamatan peserta didik yang termotivasi, yang kurang motivasi, peserta didik yang tidak termotivasi, dengan harapan proses analisa data lebih signifikan, 3)laporan hasil kerja kelompok yang dibuat secara individu lebih difokuskan, dan 4) pelaksanaan tes tertulis yang merupakan dari peningkatan motivasi dan hasil belajarpeserta didik lebih diperketat.

\section{Tahap Observasi}

Observasi guru memperoleh skor rata-rata pertemuan I $(4,21)$ dan pertemuan II $(4,64)$. Observasi peserta didik memperoleh skor ratarata pertemuan I $(4,18)$ dan pertemuan II $(4,51)$. 
Dampak dari hasil peningkatan motivasi dan hasil belajar yang dilihat dari tugas dan tes tertulis memperoleh nilai rata-rata sebesar $(79,27)$ dan $(80,90)$

\section{Tahap Refleksi}

1. Renungan atas perolehan data hasil observasi guru, observasi peserta didik, dan hasil tes tertulis sebagai dampak dari peningkatan motivasi dan hasil belajar peserta didik di kelas senyatanya.

2. Pengolahan data hasil observasi guru, observasi peserta didik dan tes tertulis

3. Mencocokkan perolehan data hasil tindakan dengan Indikator keberhasilan yang telah ditetapkan.

4. Guru memberikan hadiah/reward kepada semua peserta didik Kelas VI atas keberhasilannya dalam upaya meningkatkan motivasi dan hasil belajar yang berdampak terhadap perolehan hasil belajar sesuai dengan KKM yang telah ditetapkan.

\section{Pembahasan}

SIKLUS I

\section{Tahap Perencanaan}

Peneliti telah berhasil menyusun RPP dengan skenario penerapan Group Resume (Resume Kelompok), telah berhasil menyiapkan alat, sumber, bahan yang diperlukan dalam proses pembelajaran, menyusun instrument observasi guru maupun instrument observasi peserta didik, mengalami sedikit kendala. setelah meminta petunjuk dari pembimbing kendalapun bisa di atasi dengan baik. Dalam penyusunan alat evaluasi, peneliti tidak mengalami hambatan maupun kesulitan. Rumus yang digunakan dalam penentuan keberhasilaan hasil observasi maupun hasil tes tertulis oleh peserta didik dengan menggunakan rumus deskriptif kualitatif.

\section{Tahap Pelaksanaan}

1. Guru membagi peserta didik menjadi 5 (lima) kelompok yang anggotanya masingmasing berjumlah 6 orang peserta didik

2. Guru menjelaskan kepada peserta didik bahwa kelas mereka itu dipenuhi oleh individu-individu yang penuh bakat dan pengalaman,

3. Masing-masing kelompok dibagikan kertas plano (kertas buram koran) dan spidol untuk menuliskan resume mereka. Resume harus dapat mencakup informasi yang dapat menjual "kelompok" secara keseluruhan.

4. Diskusikan materi yang akan dibuat resume dari hasil diskusi kelompok masing-masing

5. Guru memberikan kesempatan kepada masing-masing kelompok untuk mempresentasikan resume mereka dan catat keseluruhan potensi yang dimiliki oleh keseluruhan kelompok.

Kegiatan pembelajaran diakhiri dengan tes tertulis, hal ini dimaksudkan untuk mengetahui dampak positif dari peningkatan motivasi dan hasil belajar Pendidikan Agama Islam Dan Budi Pekerti peserta didik Kelas VISD Negeri 12 Ampenan Semester satu tahun pelajaran 2019/2020 dengan penerapan pendekatan Group Resume (Resume Kelompok). Asumsi bila motivasi dan hasil belajar meningkat maka akan berdampak meningkatnya hasil belajar peserta didik.

\section{Tahap Observasi}

Observasi guru memperoleh skor rata-rata pertemuan I $(3,21)$ dan pertemuan II $(3,64)$, hasil observasi peserta didik dalam upaya peningkatan motivasi dan hasil belajar Pendidikan Agama Islam Dan Budi Pekerti peserta didik Kelas VI Semester satu tahun pelajaran 2019/2020 di SD Negeri 12 Ampenan diperoleh skor rata-rata pertemuan I $(3,30)$ dan pertemuan II $(3,57)$. Dampak dari peningkatan motivasi/belum meningkatnya motivasi dan hasil belajar peserta didik yang dilihat dari nilai tugas dan hasil tes tertulis yang materinya hanya sekitar yang diajarkan pada saat itu juga, diperoleh nilai rata-rata $(70,07)$ dan $(71,97)$ kategori cukup.

\section{Tahap Refleksi}

Hasil analisa data peningkatan motivasi dan hasil belajar pada siklus I pertemuan II ini $(3,57)$ sedangkan yang diminta dalam Indikator keberhasilan $(\geq 4,0)$, ini artinya belum berhasil. 
Jurnal Ilmiah Mandala Education

http://ejournal.mandalanursa.org/index.php/JIME/index

terakreditasi Peringkat 4 (No. SK: 36/E/KPT/2019)

Karena Indikator keberhasilan belum tercapai, penelitian tindakan kelas (PTK) dilanjutkan ke siklus II dengan harapan optimalisasi penerapan strategi pembelajaran dengan pendekatan Group Resume (Resume Kelompok) dapat meningkatkan motivasi dan hasil belajar Pendidikan Agama Islam Dan Budi Pekerti peserta didik Kelas VI Semester satu tahun pelajaran 2019/2020 di SD Negeri 12 Ampenan.

SIKLUS II

Tahap Perencanaan

Peneliti menyusun Rencana Pelaksanaan Pembelajaran (RPP) dengan memperhatikan kesalahan-kesalahan pada siklus I. peneliti lebih memfokuskan tentang Rencana strategi jitu sehingga proses pembelajaran dengan pendekatan Group Resume (Resume Kelompok) dapat terelaisasi dengan baik, karenanya dalam penyusunan skenario benarbenar dirinci dari tiap aspek pada proses pembelajaran dengan Group Resume (Resume Kelompok).

\section{Tahap Pelaksanaan}

Pada tahap pelaksanaan di siklus II ini pada dasarnya masih mengacu pada pelaksanaan siklus I, yaitu penerapan pendekatan Group Resume (Resume Kelompok).Bedanya pada siklus ini lebih dioptimalkan.

\section{Tahap Observasi}

Pada siklus II ini hasil observasi memperoleh skor rata-rata pertemuan I $(4,21)$ dan pertemuan II $(4,57)$. Upaya meningkatkan motivasi dan hasil belajarPendidikan Agama Islam Dan Budi Pekertipeserta didikKelas VISemester satu tahun pelajaran 2019/2020 di SD Negeri 12 Ampenan diperoleh skor rata-rata pertemuan I $(4,11)$ dan pertemuan II $(4,51)$, sebagai tolak ukur keberhasilan proses pembelajaran adalah hasil belajar peserta didik meningkat, dari data hasil perolehan nilai ratarata tugas dan tes tertulis adalah $(85,79)$ sementara pada siklus sebelumnya hanya $(65,12)$ berarti mengalami peningkaatan $(20,67)$.
Vol. 6. No. 1. April 2020

p-ISSN: 2442-9511 e-ISSN: 2656-5862

\section{Tahap Refleksi}

Hasil analisa data peningkatan motivasi dan hasil belajar peserta didik pada siklus II pertemuan II adalah $(4,51)$ sedangkan Indikator keberhasilan $(\geq 4,0)$. Ini artinya pada siklus II hasilnya telah melampaui Indikator keberhasilan, sedangkan hasil belajar rata-rata 80,09 dari indikator keberhasilan $\geq 75,00$, artinya telah melampaui indikator keberhasilan yang ditentukan.

Karena Indikator keberhasilan telah terbukti, maka tidak perlu ada upaya perbaikan dan penyempurnaan.Pendekatan Group Resume (Resume Kelompok) telah mampu meningkatkan motivasi dan hasil belajar peserta didik yang ditandai dengan tercapainya Indikator keberhasilan dan terjadinya peningkatan hasil belajar peserta didik."Penelitian Tindakan Kelas (PTK) dihentikan pada siklus II dengan hasil memuaskan.”

\section{SIMPULAN}

Data komulatif dari hasil penelitian tindakan kelas (PTK) dari siklus I ke Siklus II adalah sebagai berikut:

\begin{tabular}{|c|c|c|c|c|c|c|c|}
\hline \multirow{2}{*}{$\mathrm{N}_{0}$} & \multirow{2}{*}{ Jenis Kegiatall } & \multirow{2}{*}{$\begin{array}{l}\text { Indikator } \\
\text { keberlasilan! }\end{array}$} & \multicolumn{2}{|c|}{ Sillus I } & \multicolumn{2}{|c|}{ Siklus II } & \multirow{2}{*}{ Keterangan } \\
\hline & & & I & II & I & II & \\
\hline 1. & Observasi Guru & $\geq 4,00$ & 3,21 & 3,64 & 4,21 & 4,57 & Tuntas \\
\hline 2. & Observasi Peserta didik & $\geq 4,00$ & 3,30 & 3,57 & 4,11 & 4,51 & Tuntas \\
\hline 3. & Tugas & $\geq 75,00$ & 70,07 & - & 79,27 & - & Tuntas \\
\hline 4. & Tes tertulis & $\geq 75,00$ & . & 71,97 & . & 80,90 & Tuntas \\
\hline
\end{tabular}

Penerapan pendekatan Group Resume (Resume Kelompok) sangat efektif upaya untuk meningkatkan motivasi dan hasil belajarPendidikan Agama Islam Dan Budi Pekertipeserta didikKelas VISemester satu tahun pelajaran 2019/2020 di SD Negeri 12 Ampenan. Fakta telah menunjukkan perolehan rata-rata skor motivasi dan hasil belajarpeserta didikpertemuan II pada siklus I(3,57), sedangkan pada siklus II $(4,51)$, hasil belajar siklus I $(71,02)$ dan Siklus II $(80,09)$ sudah melampaui Indikator keberhasilan yang ditetapkan. Penelitian dinyatakan "berhasil" dan dihentikan pada siklus II. 


\section{SARAN}

Disarankan kepada guru sejawat untuk melaksanakan Penelitian Tindakan Kelas (PTK) dalam upaya untuk meningkatkan motivasi dan atau hasil belajar peserta didik sesuai dengan mata pelajaran masing-masing.

Disarankan kepada para semua peserta didik Kelas VISD Negeri 12 Ampenan untuk membiasakan belajar dengan pendekatan yang kontekstual utamanya strategi yang mampu membangkitkan motivasi dan hasil belajar peserta didik yang dampaknya hasil belajar dapat ditingkatkan seperti yang diharapkan.

\section{DAFTAR PUSTAKA}

Arikunto, s. 2009, Penelitian Tindakan Kelas, Jakarta : Bumi Aksara.

Harun Rasyid dan Mansur, 2008, Penilaian Hasil Belajar, Bandung : CV Wacana Prima.

Hisyam Zaini, CTSD, 2007, Strategi Pembelajaran Aktif, dalam http://ajoefahmi.blogspot.com/2016/04 /strategi-pembelajaran-groupresume.html, diambil pada tanggal 27 September 2019 pada pukul 11.05 wita Lukmanul A, 2008, Perencanaan Pembelajaran, Bandung : CV Wacana Prima.

Mukhtar, 2003, Prosedur Penilaian, Jakarta : Rineka Cipta.

Nurhadi, 2003, Yasin ,B dan Sendule.A, 2003, Kontekstual dan Penerapannya dalam KBK, Malang : Unitipetas Negeri Malang.

Robert E Slavin, 2010, Cooperative Learning Teori, riset dan Praktik, Bandung : Nusa Media.

Sardiman, 2007, Indikator Dan Motivasi dan hasil belajar Mengajar, Jakarta : Raja Grafindo Perkasa.

Supriono, 2009, Cooperative Learning Teori dan Aplikasi PAIKEM, Yogyakarta : Pustaka Pelajar.

Susilawati, E., Sarnita, F., Gumilar, S., Erwinsyah, A., Utami, L., \& Amiruddin, A. (2019, November). Using inductive approach (IA) to enhance students' critical thinking
(CT) skills. In Journal of Physics: Conference Series (Vol. 1280, No. 5, p. 052035). IOP Publishing. 